GOOD DESIGN TO HELP YOU

\section{Eammatas \\ Guide}

Shows how the chapter covers each exam group's syllabus

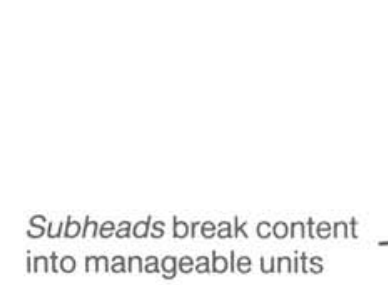

The Pattern of Questions in the exam into manageable units
Text-the

information and

facts that you

need in digestible

form

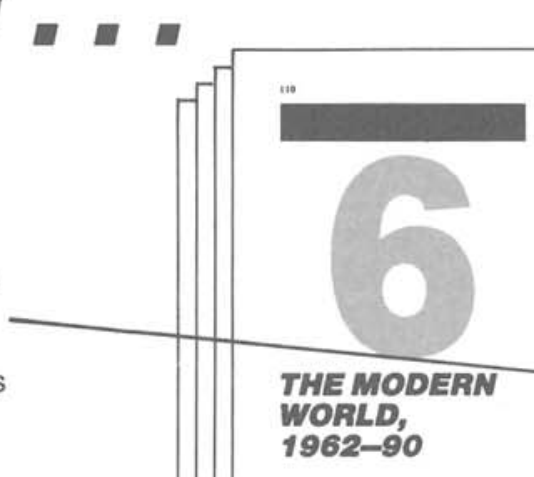

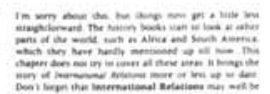

Examination Guide

mancins s.

$x=-10$

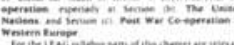

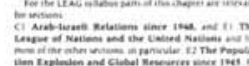

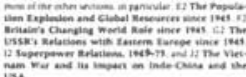

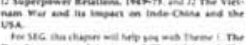
sind

\title{
Topic Guide
}
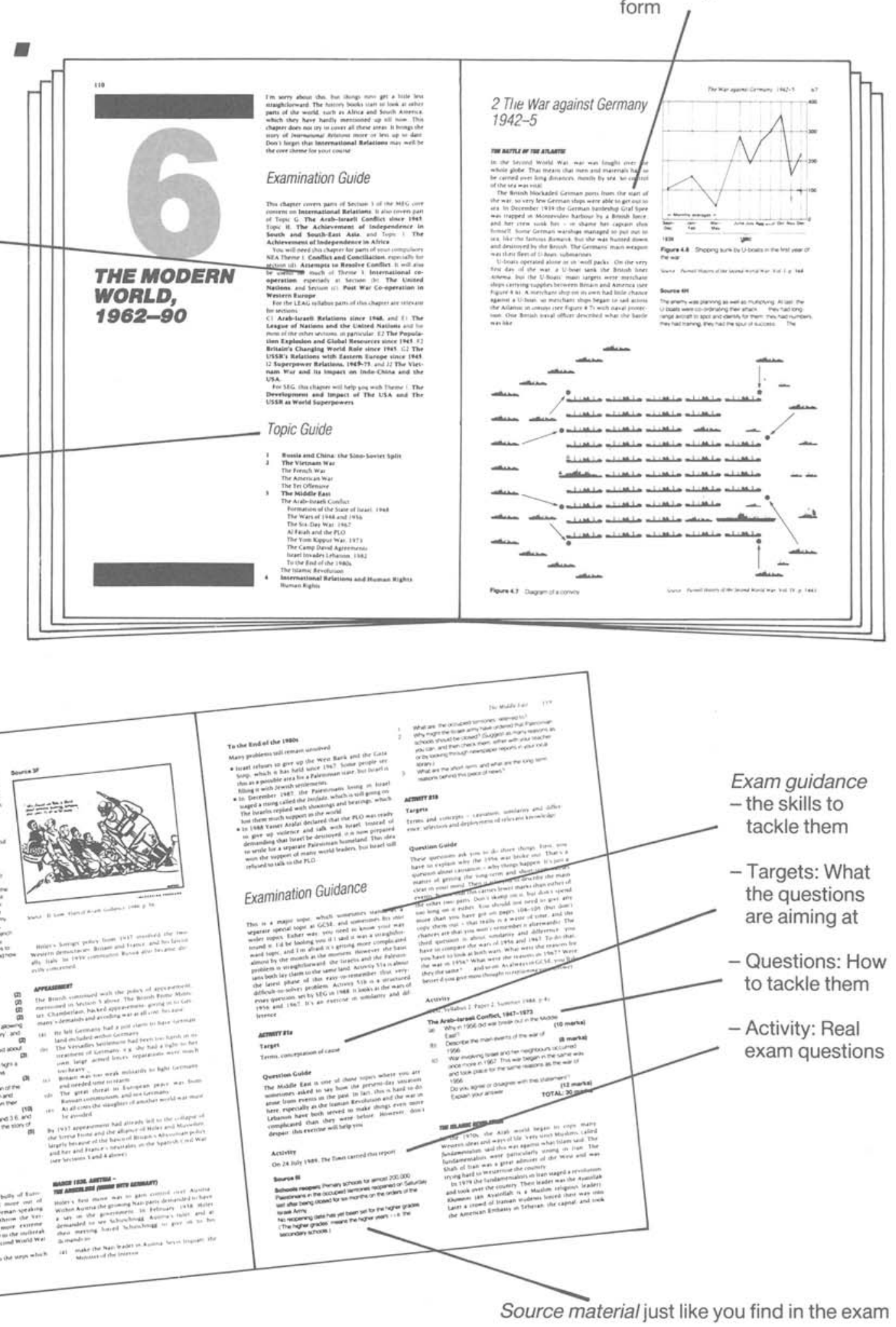


\section{THIS BOOK ... .}

\section{Success and Success}

Our book has two main purposes:

- To help you understand many of the major events, ideas and issues which affect you in your everyday lives

- To ensure success when you take the GCSE Modern World History examination papers at the end of your course

\section{History is relevant to you}

Most of the people we have written about are dead and buried, but what they did lives on today. Open a newspaper or listen to the radio or television and you see the direct impact History has upon your life.

An example of what we mean

If in 1914 you had asked History teachers about communism, they would probably not have heard of the word. Today your History teacher will be dealing with communism for much of this course - communists rule about half of the world's people. You can only understand what communism means by looking at how it developed and changed in countries like Russia and China in this century.

\section{Exam Coverage}

The four main Examining Groups, LEAG (London), MEG (Midland), NEA (Northern) and SEG (Southern) Modern World History syllabuses cover over 100 separate topics. I know, I worked carefully through all the syllabuses and counted them!

So we have picked out the key content common to all four syllabuses. The chapters are arranged in a logical order which reflects the pattern of Modern World History GCSE papers.

\section{Chapter 1}

shows how to analyse your own course, how to handle the kinds of questions which you will have to answer, how to interpret sources and how to organise your revision programme.

Chapters 2-6 an outline course on International Relations 1919-1990

Chapters 7-11 the five major topics for study in depth

The First World War - Chapter 7
Russia 1917-1953 - Chapter 8
Germany 1919-1945 - Chapter 9
America 1919-1941 - Chapter 10
China 1919-1980 - Chapter 11

In your own course you will probably have to cover two or three of the topics contained in chapters 7-11. Hopefully the common core in this book will cover at least $80 \%$ of what you need for the final examination. 


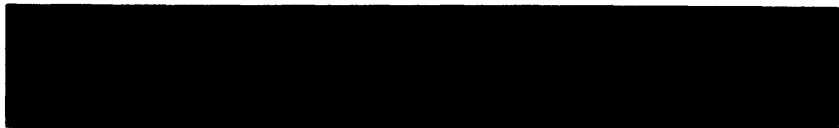

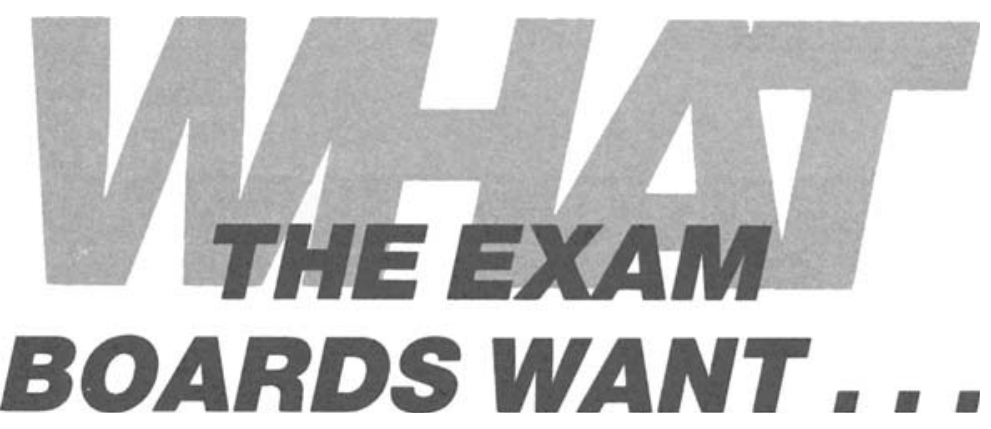

\section{WORKOUT MODERN WORLD HISTORY GCSE}

2 International Relations 1914-29

3 International Relations 1929-41

4 The Second World War

5 The Cold War 1945-1962

6 The Modern World 1962-1990

7 The First World War

8 Russia 1917-56

9 Germany 1919-45

\begin{tabular}{|c|c|}
\hline $\begin{array}{c}\text { MEG } \\
\text { MIDLAND EXAM GROUP }\end{array}$ & $\begin{array}{l}\text { LEAG } \\
\text { LONDON EXAM GROUP }\end{array}$ \\
\hline $\begin{array}{l}\text { The Search for International Order } \\
\text { between } 1919 \text { and } 1929 \\
\text { (Compulsory Element, Paper 1) }\end{array}$ & $\begin{array}{l}\text { E1. The League of Nations and the } \\
\text { United Nations (Paper 1) } \\
\text { F1. Fascism in Italy and } \\
\text { Germany (Paper 1) }\end{array}$ \\
\hline $\begin{array}{l}\text { The Collapse of International Order in the } \\
1930 \text { s } \\
\text { (Compulsory Element, Paper } 1 \text { ) }\end{array}$ & $\begin{array}{l}\text { E1. The League of Nations and the } \\
\text { United Nations (Paper 1) } \\
\text { F1. Fascism in Italy and } \\
\text { Germany (Paper 1) }\end{array}$ \\
\hline $\begin{array}{l}\text { World War II is included as element in the } \\
\text { optional topic, Germany, } 1919-45 \text {. }\end{array}$ & $\begin{array}{l}\text { 11. Aspects of the Second World } \\
\text { War (Paper 1) }\end{array}$ \\
\hline $\begin{array}{l}\text { Tension and Co-operation since } 1945 \\
\text { (Compulsory Element, Paper 1) }\end{array}$ & $\begin{array}{l}\text { 12. Super-Power Relations, } \\
\text { 1945-75 (Paper 2) } \\
\text { C 1. Arab-Israeli Relations since } \\
1948 \text { (Paper 1) }\end{array}$ \\
\hline $\begin{array}{l}\text { Tension and Co-operation since } 1945 \\
\text { (Compulsory Element, Paper 1) }\end{array}$ & $\begin{array}{l}\text { I2. Super-Power Relations, } \\
\text { 1945-75 (Paper 2) } \\
\text { C 1. Arab-Israeli Relations since } \\
1948 \text { (Paper 1) }\end{array}$ \\
\hline $\begin{array}{l}\text { The First World War } \\
\text { (Optional topic, Paper 2) }\end{array}$ & $\begin{array}{l}\text { J1. The Impact of the First World War } \\
\text { on British Society (Paper 1) }\end{array}$ \\
\hline $\begin{array}{l}\text { Russia, 1917-41 } \\
\text { (Optional Topic, Paper 2) }\end{array}$ & $\begin{array}{l}\text { G 1. The Russian - ovolution and the } \\
\text { Establis . uf the Soviet State, } \\
1917-41 \text { (Paper 1) }\end{array}$ \\
\hline $\begin{array}{l}\text { Germany, } 1919-45 \\
\text { (Optional topic, Paper 2) }\end{array}$ & $\begin{array}{l}\text { F1. Fascism in Italy and Germany, } \\
1919-39 \text { (Paper 1) }\end{array}$ \\
\hline
\end{tabular}




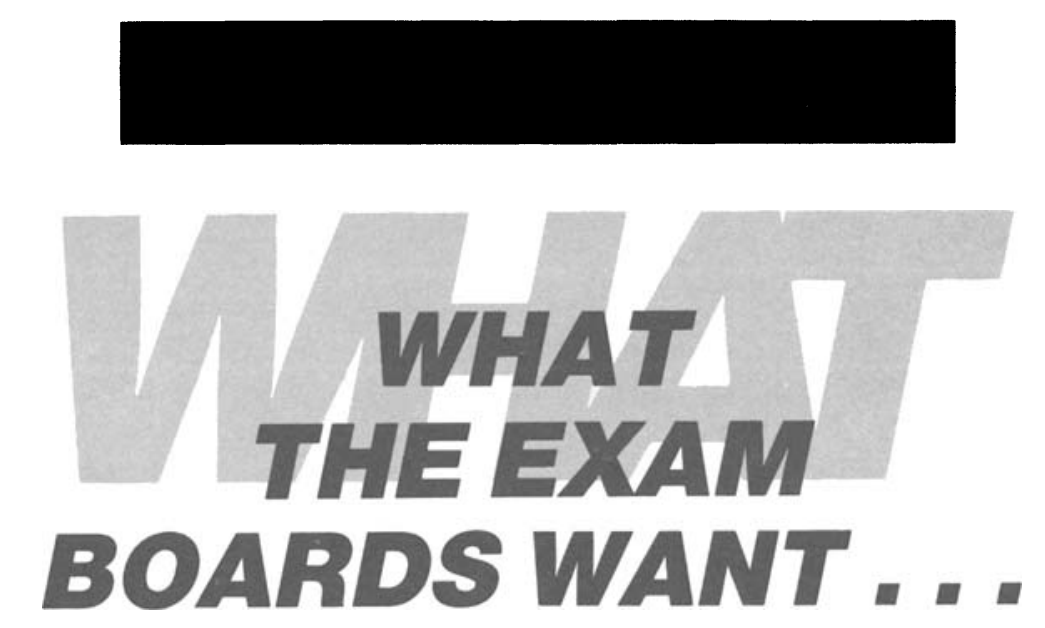

10 The United States of America, 1919-41

11 China 1919-80

2 International Relations 1914-29

3 International Relations 1929-41

4 The Second World War

\begin{tabular}{|l|l|}
\hline $\begin{array}{l}\text { The United States of America, 1919-41 } \\
\text { (Optional Topic, Paper 2) }\end{array}$ & H2. $\begin{array}{l}\text { Boom, Depression and New Deal in } \\
\text { the United States, } \\
1919-41 \quad \text { (Paper 2) }\end{array}$ \\
\hline $\begin{array}{l}\text { Communism in China since 1949 } \\
\text { (Optional Topic, Paper 2) }\end{array}$ & A2. $\begin{array}{l}\text { The Emergence of a Communist } \\
\text { State in China, 1920 to the death of } \\
\text { Mao Zedong (Mao Tse } \\
\text { Tung) (Paper 2) }\end{array}$ \\
\hline
\end{tabular}

\begin{tabular}{|c|c|}
\hline $\begin{array}{c}\text { NEA } \\
\text { NORTHERN EXAM ASSOCIATION }\end{array}$ & $\begin{array}{c}\text { SEG } \\
\text { SOUTHERN EXAM GROUP }\end{array}$ \\
\hline $\begin{array}{l}\text { Conflict and Conciliation, Compulsory } \\
\text { theme (Paper 1) } \\
\text { Peacemaking after the First World War } \\
\text { International Co-operation, Optional } \\
\text { theme (Paper 2) } \\
\text { - The League of Nations }\end{array}$ & $\begin{array}{l}\text { Peace to World War, 1918-41 } \\
\text { (Optional Theme, Paper 1) }\end{array}$ \\
\hline $\begin{array}{l}\text { Conflict and Conciliation, Compulsory } \\
\text { theme (Paper 1) } \\
\text { - Causes of the Second World War } \\
\text { International Co-operation, Optional } \\
\text { theme (Paper 2) } \\
\text { - The League of Nations } \\
\text { - The failure of Collective Security in the } \\
\text { 1930s }\end{array}$ & $\begin{array}{l}\text { Peace to World War, 1918-41 } \\
\text { (Optional Theme, Paper 1) }\end{array}$ \\
\hline $\begin{array}{l}\text { Conflict and Conciliation, Compulsory } \\
\text { theme (Paper 1) } \\
\text { - Developing techniques of warfare in } \\
\text { the Second World War } \\
\text { - The Home Front in Britain } \\
\text { - German conquest and occupation in } \\
\text { the Second World War }\end{array}$ & $\begin{array}{l}\text { Military Events of the Second World War, } \\
1939-45 \\
\text { (Optional Topic, Paper 2) }\end{array}$ \\
\hline
\end{tabular}




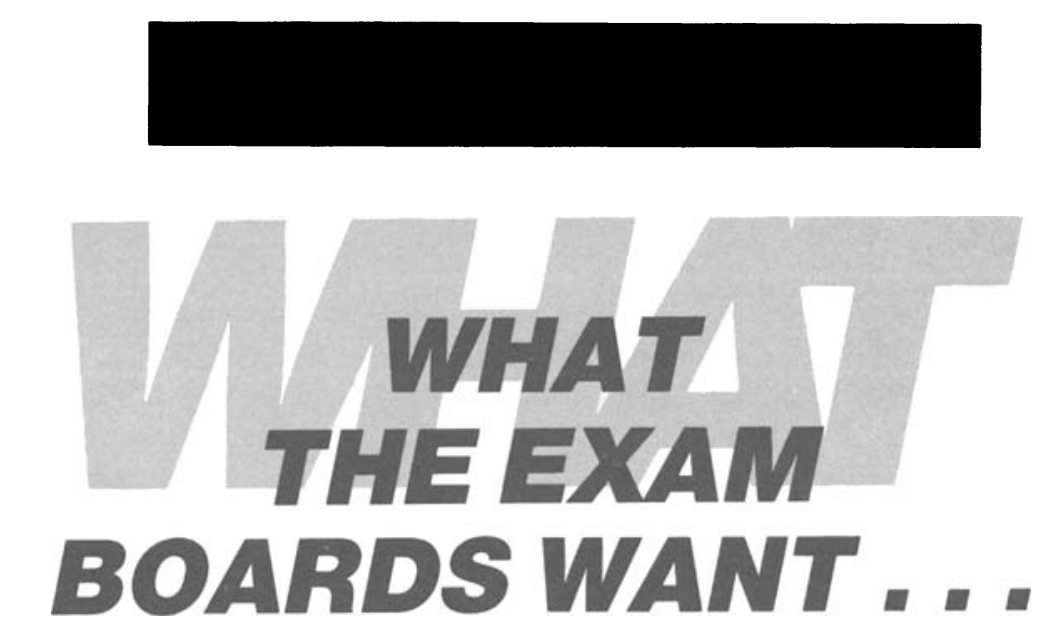

5 The Cold War 1945-1962

6 The Modern World 1962-1990

7 The First World War

8 Russia 1917-56

9 Germany 1919-45

10 The United States of America 1919-41

11 China 1919-80

\begin{tabular}{|c|c|}
\hline $\begin{array}{l}\text { Conflict and Conciliation, Compulsory } \\
\text { theme (Paper 1) } \\
\text { - The Cold War } \\
\text { - The Nuclear Arms Race } \\
\text { International Co-operation, Optional } \\
\text { theme (Paper 2) } \\
\text { - The United Nations } \\
\text { - Post War Co-operation in Western } \\
\text { Europe }\end{array}$ & $\begin{array}{l}\text { The USA and the USSR as World } \\
\text { Superpowers since } 1945 \\
\text { (Compulsory Theme, Paper 1) } \\
\text { The Arab-Israeli conflict, 1945-79 } \\
\text { (Optional Topic, Paper 2) }\end{array}$ \\
\hline $\begin{array}{l}\text { Conflict and Conciliation, Compulsory } \\
\text { theme (Paper 1) } \\
\text { - Guerilla Warfare in Vietnam } \\
\text { International Co-operation, Optional } \\
\text { theme (Paper 2) } \\
\text { - The United Nations } \\
\text { - Post War Co-operation in Western } \\
\text { Europe }\end{array}$ & $\begin{array}{l}\text { The USA and the USSR as World } \\
\text { Superpowers since } 1945 \\
\text { (Compulsory Theme, Paper 1) } \\
\text { The Arab-Israeli conflict, 1945-79 } \\
\text { (Optional Topic, Paper 2) }\end{array}$ \\
\hline $\begin{array}{l}\text { Conflict and Conciliation, Compulsory } \\
\text { theme (Paper 1) } \\
\text { - The reasons why Sarajevo led to war } \\
\text { - The Western Front, 1914-18 } \\
\text { - The Home Front in Britain }\end{array}$ & $\begin{array}{l}\text { Britain and the Western Front, 1914-18 } \\
\text { (Optional Topic, Paper 2) }\end{array}$ \\
\hline $\begin{array}{l}\text { The Russian Revolution: Lenin and Stalin } \\
\text { (Optional Topic, Paper 2) }\end{array}$ & $\begin{array}{l}\text { Russia, 1917-41 } \\
\text { (Optional Topic, Paper 2) }\end{array}$ \\
\hline $\begin{array}{l}\text { Germany, 1918-39 } \\
\text { (Optional Topic, Paper 2) }\end{array}$ & $\begin{array}{l}\text { Germany, 1919-39 } \\
\text { (Optional Topic, Paper 2) }\end{array}$ \\
\hline $\begin{array}{l}\text { The USA in the 1920s and 1930s } \\
\text { (Optional Topic, Paper 2) }\end{array}$ & $\begin{array}{l}\text { Internal Developments in the USA, } \\
1919-41 \\
\text { (Optional Topic, Paper 2) }\end{array}$ \\
\hline Communist China & $\begin{array}{l}\text { China, 1934-68 } \\
\text { (Optional Topic, Paper 2) }\end{array}$ \\
\hline
\end{tabular}




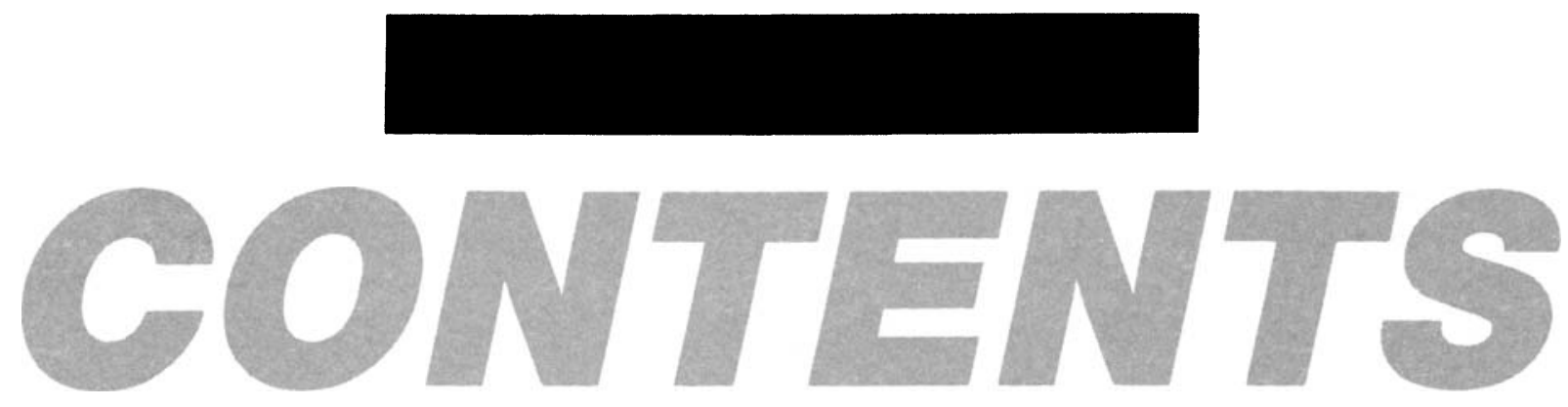

Course and Revision Planning

10

The First World War,

1914-18 133

Russia, 1917-56

146

1919-29 21

Relations,

1919-29 21

International Relations,

1929-41 41

Germany, 1919-45 170

The Second World War

59

The United States of America, 1919-41 184

The Cold War, c. 1945-68

85

China, 1919-80

203

The Modern World,

1962-90 111 


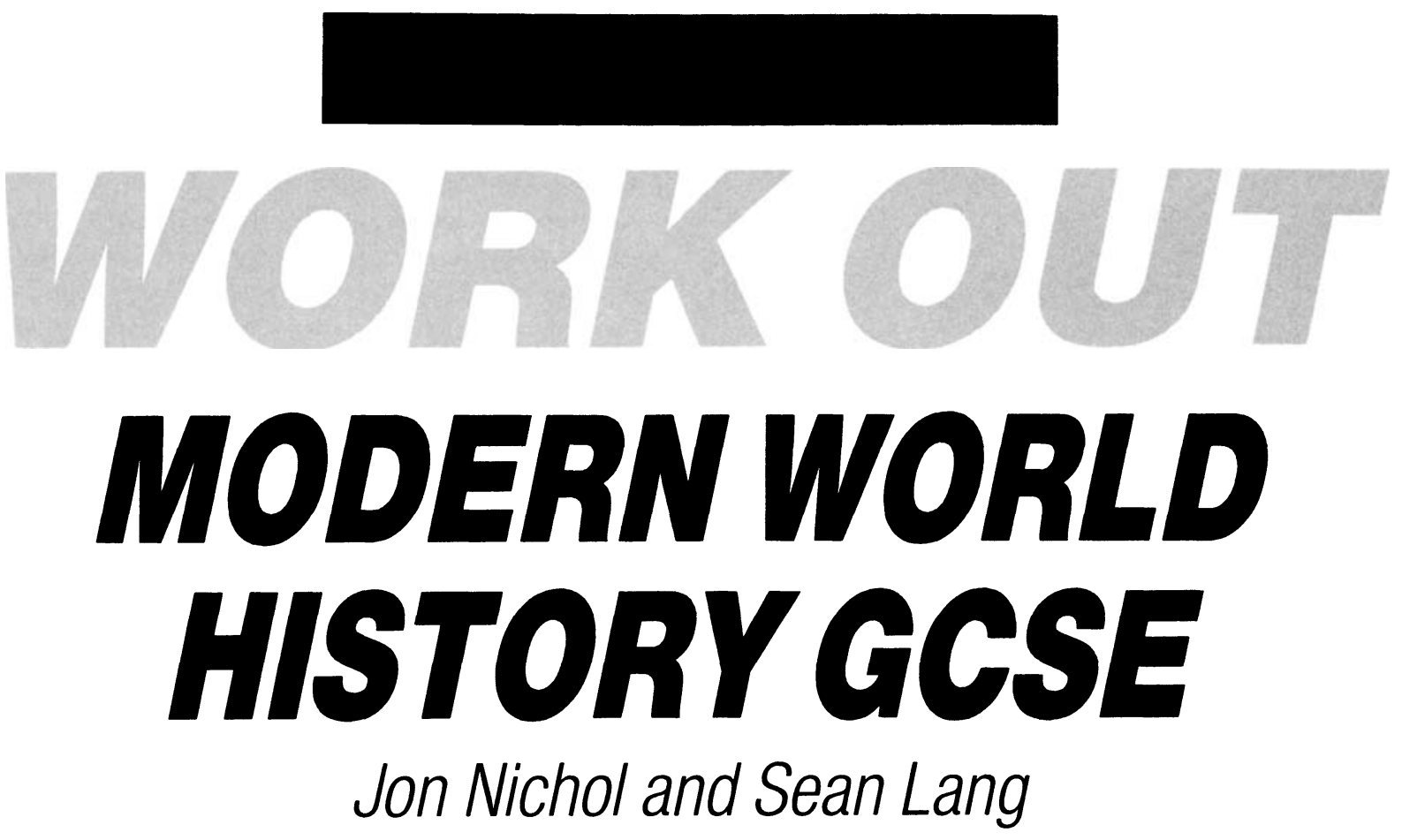

School of Education, University of Exeter

Jon Nichol wrote chapters $1-3$ and 7-11,

Sean Lang wrote chapters 4-6

\section{Acknowledgements}

The authors and publishers wish to thank the following for permission to use copyright material: London East Anglian Group, Midland Examining Group, Northern Examining Association comprising Associated Lancashire Schools Examining Board, Joint Matriculation Board, North Regional Examinations Board, North West Regional Examinations Board and Yorkshire \& Humberside Regional Examinations Board, and Southern Examining Group for questions from specimen and past examination papers; Solo Syndication for five cartoons by David Low included in Years of Wrath, A Cartoon History 1932-1945 by David Low, Gollancz, 1986.

Other acknowledgements for use of figures and tables is as shown within the text.

The authors and publishers also wish to acknowledge the following photograph sources: Bilderdienst Suddeutscher page 180; Camera Press pages 62, 103 bottom right, 125, 213, 218; Chinese National Army Museum page 99; Hulton Picture Company pages 14, 68, 144 187, 188; By kind permission of the Trustees of the Imperial War Museum pages 70, 81 top, 87 top right, 144; Popperfoto pages 87 top left, 87 bottom, 111, 115, 118, 151, 153; Roger-Viollet pages 75 , 157; John Sadovy page 102; Syndication International Ltd page 103 bottom left; Topham Picture Library pages 81 bottom, 103 top, 114 , 126, 192; Ullstein Bilderdienst pages 173, 179, 181 right; UNRWA/ George Nehmeh page 117; US National Archives page 93; The Wiener Library page 181 left.

Every effort has been made to trace all the copyright holders but if any have been inadvertently overlooked the publishers will be pleased to make the necessary arrangement at the first opportunity.

\section{(C) Jon Nichol and Sean Lang 1990}

All rights reserved. No reproduction, copy or transmission of this publication may be made without written permission.

No paragraph of this publication may be reproduced, copied or transmitted save with written permission or in accordance with the provisions of the Copyright, Designs and Patents Act 1988, or under the terms of any licence permitting limited copying issued by the Copyright Licensing Agency, 33-4 Alfred Place, London WCIE 7DP.

Any person who does any unauthorised act in relation to this publication may be liable to criminal prosecution and civil claims for damages.

First published 1990

Published by

MACMILLAN EDUCATION LTD

Houndmills, Basingstoke, Hampshire RG21 2XS

and London

Companies and representatives throughout the world

Editorial, design and production

by Hart McLeod, Cambridge

British Library Cataloguing in Publication Data

Nichol, Jon

Workout modern world history GCSE.

1. World, 1990-

I. Title II. Lang, Sean

ISBN 978-0-333-46875-3

ISBN 978-1-349-10323-2 (eBook)

DOI 10.1007/978-1-349-10323-2 